University of Rhode Island

DigitalCommons@URI

The Rhode Island Current Conditions Index

Economics

7-2005

\title{
Rhode Island Current Conditions Index - July 2005
}

Leonard Lardaro

University of Rhode Island, lardaro@uri.edu

Follow this and additional works at: https://digitalcommons.uri.edu/ricci

Part of the Econometrics Commons

Terms of Use

All rights reserved under copyright.

\section{Recommended Citation}

Lardaro, Leonard, "Rhode Island Current Conditions Index -- July 2005" (2005). The Rhode Island Current Conditions Index. Paper 100.

https://digitalcommons.uri.edu/ricci/100

This Article is brought to you for free and open access by the Economics at DigitalCommons@URI. It has been accepted for inclusion in The Rhode Island Current Conditions Index by an authorized administrator of DigitalCommons@URI.For more information, please contact digitalcommons-group@uri.edu. 


\section{GURRENT}

The third quarter started off disappointingly, as the Current Conditions Index fell from its recent multi-year high of 92 in June to 58 in July. For July, only seven indicators improved. Yet there was still good news. While four indicators that had improved in June failed to do so again in July, only two of these showed significant declines. And, Rhode Island continues to move forward in terms of ongoing Labor Force growth, with layoffs and long-term unemployment both continuing to decline. This, you might recall from previous reports, points to the reversal of some of the more pressing economic concerns Rhode Island began 2005 with.

First, the good news. Rhode Island's economy continues to grow, although the pace of activity has apparently slowed from what we observed in June. Payroll employment in July grew by 1.3 percent compared to last July, giving Rhode Island the rank of third in New England. The growth in labor demand, in terms of Help Wanted Advertising, continued to accelerate,

\begin{tabular}{lc}
\multicolumn{2}{c}{ CCI Indicators - \% Change } \\
Government Employment & 0.6 Y \\
US Consumer Sentiment & -0.2 \\
Single-Unit Permits & -4.9 \\
Retail Sales & -11.3 \\
Help Wanted Advertising & $1.5 \mathrm{Y}$ \\
Priv. Serv-Prod Employment & $2.3 \mathrm{Y}$ \\
Man-Hours Manufacturing & -4.7 \\
Manufacturing Wage & $0.0 \mathrm{Y}$ \\
Labor Force & $1.2 \mathrm{Y}$ \\
Benefit Exhaustions & $-7.1 \mathbf{Y}$ \\
New Claims & $-3.1 \mathbf{Y}$ \\
Unemployment Rate & 0.0 \\
\multicolumn{1}{|c}{ Y = I mproved Value } &
\end{tabular}

rising by 1.5 percent in July. As this was occurring, layoffs, in terms of New Claims declined by 3.1 percent, and long-term unemployment, measured by Benefit Exhaustions, fell by a respectable 7.1 percent. More importantly, July marked the second consecutive month for which both New Claims and Benefit Exhaustions improved, and only the sixth time in the last year this has occurred.

Government Employment grew at its fastest rate since April $(0.6 \%)$, keeping this indicator above the 66,000 level once again. Along with this, the growth in Private ServiceProducing Employment accelerated to 2.3 percent in July, matching the highest rate we have witnessed in the past year (tied with January).
July saw another significant rise in our Labor Force $(+1.2 \%)$ which was the fifth consecutive rise in this indicator, a very positive sign. While our Unemployment Rate remained unchanged from last July at 5.1 percent, the fact that this occurred along with a rising Labor Force allows this to be viewed as a neutral rather than a negative performance. I believe that the lower Unemployment Rates we witnessed last year, which were accompanied by a falling Labor Force, did not accurately reflect labor market tightness here. July's data provide further evidence that the troubling Labor Force declines we witnessed last year have apparently ended.

Economic weakness in July was concentrated in our manufacturing sector, retail trade, and new home construction. Manufacturing Man-hours slid by 4.7 percent compared to last July, which was among its most rapid rates of decline in the past year. As a result, the Manufacturing Wage was essentially flat in July, at $\$ 13.08$. At least its dollar value continues to exceed $\$ 13$. Retail Sales, which has been one of our strongest indicators for quite a while, fell sharply in July, after posting a significant rise in June. Accompanying this was an slight decline in US Consumer Sentiment, 0.2 percent, its seventh drop in the last year. New home construction, as measured by Single-Unit Permits, fell by 4.9 percent in July, its tenth decline in the last twelve months.

The dramatic one-month decline in the $\mathrm{CCl}$ should not be viewed as a major weakening of our state's economy. Instead, the June and July $\mathrm{CCl}$ values show that we have moved beyond early year weakness. The remainder of this year may well see our economy slow, as the pace of housing continues to moderate and energy prices take a heavy toll on consumer spending and business profitability. Was May Rhode Island's bottom for 2005? We'll have to wait and see.

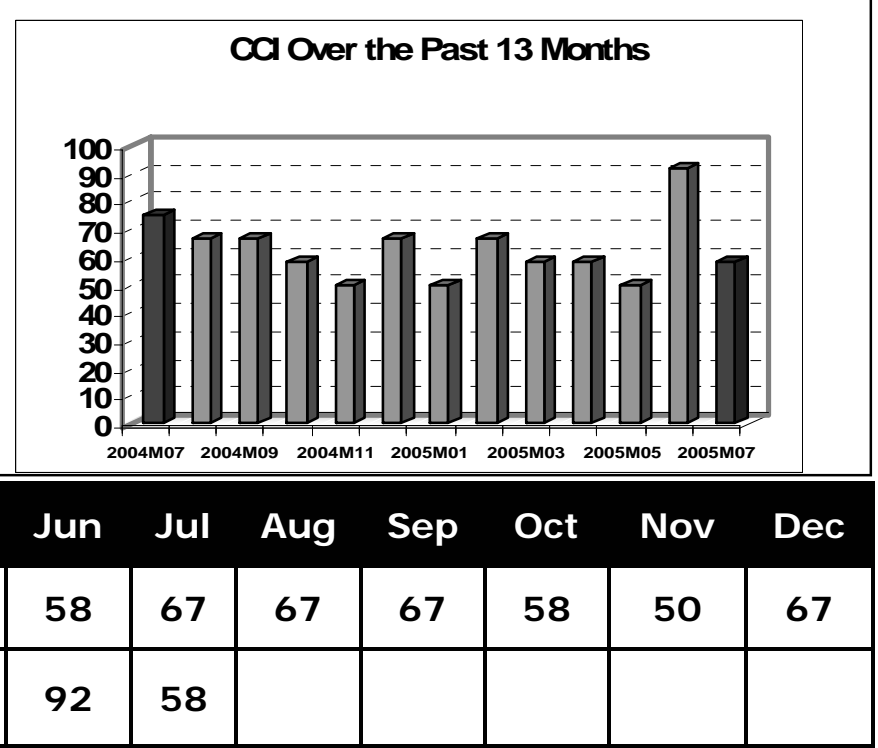

